\title{
The Long-Run Performance Following Convertible Debt Offerings: Does The Design Matter?
}

Khalid El Badraoui, ESC Rennes School of Business and CREM UMR CNRS 6211, France Jamal Ouenniche, The University of Edinburgh, Business School, UK and ESC Rennes School of Business, France

\begin{abstract}
This paper examines the impact of convertible debt design on the long-run stock price performance of the issuing firms in France. More specifically, we divide French convertible bonds $(C B s)$ into three categories; namely, debt-like, mixed, and equity-like CBs, based on their total conversion probability, which integrates the possibility of early exercise of the call feature. In line with previous empirical studies, our results show that French CB issuers experience a substantial increase in their stock price profitability before the offering followed by significant underperformance over the three year post-issue event window. However, the breakdown of our sample into three groups of CBs depending on their design reveals, on one hand, a strong evidence of stock price run-up before the offering only for equity-like and mixed CBs. On the other hand, the post-issue performance is worse only for equity-like issuers, indicating that the post-issue performance is poorer the more the convertible debt issuer's stock is over-valued prior to the offering. This finding is consistent with the market timing hypothesis.
\end{abstract}

Keywords: Convertible Bonds; Operating Performance; Security Design; Stock Price Performance

\section{INTRODUCTION}

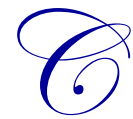

onvertible debt is a hybrid security which has both equity and straight debt characteristics. The main issue companies face when designing a convertible bond (CB) is to specify security features such as conversion ratio, call price, call period, and maturity. All of these features can be aggregated into a single measure of equity likeness such as the probability that the $\mathrm{CB}$ will be converted into equity at maturity.

Several studies have investigated the long-run stock price profitability of firms over the period surrounding the issuance of CBs in US (e.g., Lee \& Loughran, 1998; Spiess \& Affleck-Graves, 1999), in Japan (e.g., Kang et al., 1999; Cheng et al., 2005) as well as in Europe (e.g., Abhyankar \& Ho, 2006). The main conclusion of these studies is that issuing firms experience a large increase in their stock price performance before the transaction followed by a significant stock price downturn over a post-offering period of three to five years. However, there is no evidence of the impact of the CB design on the long-run performance of the issuing firms. Indeed, Lewis et al. (1999, 2003), amongst other authors, found that firms design CBs to mitigate different costs of external financing. Therefore, these studies document a significant variation in the market response to the announcement of new $\mathrm{CB}$ issues depending on whether investors perceive the $\mathrm{CB}$ as a debt-like, mixed or equity-like security. In this paper, we extend the existing literature by shedding light on the relationship between convertible debt design and the long-term stock price and operating performance of the issuing firm. Unlike previous studies on the design of convertible debt (e.g., Burlacu, 2000; Lewis et al., 2003; Dutordoir \& Van de Gucht, 2007; Lee et al., 2009), our classification of CBs is not based on the probability that the bond will be converted into equity at maturity, as computed using the standard BlackScholes model, but rather using the total conversion probability derived from André-Le Pogamp and Moraux (2004)'s valuation method of callable CBs. The latter takes into account the probability of early conversion induced by the call feature and thus provides a more accurate and complete security design measure. 
Our empirical tests are conducted on a sample of 133 CB issues by French firms during the period 19902007. Consistent with previous empirical evidence (e.g., Lee \& Loughran, 1998; Spiess \& Affleck-Graves, 1999), we find that $\mathrm{CB}$ issuers experience a significant downturn in their stock price and operating performance following the offering. We also find that CB issuing firms typically have superior stock price returns pre-issue as compared to the non-issuing firms. However, further analysis of the issuers' performance based on whether the CB was designed as equity-, mixed or debt-like security reveals that the behaviour of the long-run stock price and operating performance differs across these issuer classes. Indeed, only CB offerings with a strong equity component (i.e., equity and mixed-like) are issued prior to reliable share price appreciation. Debt-like issuers, however, do not experience any improvement in their performance prior to the offering. Also, post-issue stock returns and operating performance downturn is more pronounced and significant for equity-like issuers compared to mixed- and debt-like issuers. In sum, our results suggest that managers follow the recommendation of the pecking order and the market timing theory and issue CBs with strong equity component (i.e., equity- and mixed-like CBs) when firm's common stock is more likely to be over-valued. Indeed, selling CBs with an over-valued conversion option to investors will increase financial slack and reduce the interest costs of the CB below the level required in a straight debt offering. As a consequence of this managers' opportunistic behaviour, earnings and stock prices significantly decline after the transaction. This decline is more noticeable for issuers that have had larger stock price run-up, specifically equitylike issuers.

The remainder of the paper is organized as follows. Section 2 presents the literature review and hypotheses. Section 3 describes the sample characteristics and provides the research design. Section 4 provides empirical results. Finally, Section 5 concludes the paper.

\section{LITERATURE REVIEW AND HYPOTHESIS STATEMENT}

Several studies have investigated the long-term behaviour of firms' stock price before and subsequent to convertible debt offerings. Using a sample of 986 CBs offerings made by US firms over the period 1975-1990, Lee and Loughran (1998) found out, on one hand, that CB issuers over-perform both their matched counterparts and NYSE/AMEX value weighted index by $13 \%$ and $31 \%$ during the year prior to the offering, respectively. On the other hand, these authors report that CB issuers experience a substantial decline in their stock price performance over the five-year period following the CBs offer. This under-performance is estimated at $30.4 \%$ over a post-issue period of five years. As confirmed by Table 1, similar patterns are reported by subsequent studies conducted in different countries and over various periods.

Table 1: Previous Studies on Long-Run Stock Price Performance Following CB Issues

\begin{tabular}{|c|c|c|c|c|c|c|c|}
\hline \multirow{2}{*}{ Author(s) } & \multirow{2}{*}{ Period } & \multirow{2}{*}{$\begin{array}{l}\text { Sample } \\
\text { Size }\end{array}$} & \multirow{2}{*}{ Benchmark(s) } & \multicolumn{4}{|c|}{ Stock Price Performance (in \%) } \\
\hline & & & & \multicolumn{2}{|c|}{ Pre-Issue } & \multicolumn{2}{|c|}{ Post-Issue } \\
\hline $\begin{array}{l}\text { Lee and Loughran } \\
\text { (1998) }\end{array}$ & $1975-1990$ & 986 & $\begin{array}{c}\text { Market index } \\
\text { Reference portfolio }\end{array}$ & $\begin{array}{c}31.00^{\# \mathrm{EW}} \\
13.20^{\#(\mathrm{EW})}\end{array}$ & $\begin{array}{l}1 \text { year } \\
1 \text { year }\end{array}$ & $\begin{array}{l}-34.5^{* * *(E W)} \\
-30.4^{\#(E W)}\end{array}$ & $\begin{array}{l}5 \text { years } \\
5 \text { years }\end{array}$ \\
\hline $\begin{array}{l}\text { McLaughlin et al. } \\
(1998)\end{array}$ & $1980-1993$ & 828 & Reference portfolio & $17.3^{* * *} \mathrm{EW}$ & 1 year & $-11.4^{* *(\mathrm{EW})}$ & 3 years \\
\hline $\begin{array}{l}\text { Spiess and } \\
\text { Affleck-Graves } \\
\text { (1999) }\end{array}$ & 1975-1989 & 400 & $\begin{array}{l}\text { Control firm } \\
\text { Factors model }\end{array}$ & $112.34^{* * *} \mathrm{EW}$ & 5 years & $\begin{array}{c}-36.95^{* * *(E W)} \\
-0.31^{* *(a)(\mathrm{EW})} \\
-0.25^{(\mathrm{a})(\mathrm{VW})}\end{array}$ & $\begin{array}{l}5 \text { years } \\
5 \text { years }\end{array}$ \\
\hline $\begin{array}{l}\text { Dichev and } \\
\text { Piotroski (1999) }\end{array}$ & 1964-1991 & 1193 & $\begin{array}{c}\text { Reference portfolio } \\
\text { Factors model }\end{array}$ & & & 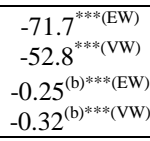 & 5 years \\
\hline Lewis et al. (2001) & $1979-1990$ & 566 & $\begin{array}{l}\text { Market index } \\
\text { Control firm }\end{array}$ & $55.80^{\#(\mathrm{EW})}$ & 5 years & $\begin{array}{l}-5.80^{\#(\mathrm{EW})} \\
-5.30^{\#(\mathrm{EW})}\end{array}$ & $\begin{array}{l}5 \text { years } \\
5 \text { years }\end{array}$ \\
\hline UK Data & & & & & & & \\
\hline & 1982-1996 & 152 & Market index & $\begin{array}{l}41.59^{* * *(E W)} \\
38.83^{* * *(V W)}\end{array}$ & 3 years & $\begin{array}{l}-14.10^{*(\mathrm{EW})} \\
-10.84^{* *(\mathrm{VW})}\end{array}$ & 3 years \\
\hline $\begin{array}{l}\text { Abhyankar and } \\
\text { Ho (2006) }\end{array}$ & & & Reference portfolio & $\begin{array}{l}46.91^{* * *(\mathrm{EW})} \\
40.74^{* * *(\mathrm{VW})}\end{array}$ & 3 years & $\begin{array}{l}-11.90^{\mathrm{NS}(\mathrm{EW})} \\
-7.62^{\mathrm{NS}(\mathrm{VW})} \\
0.29^{\mathrm{NS}(\mathrm{a})(\mathrm{EW})} \\
-0.23^{\mathrm{NS}(\mathrm{a})(\mathrm{VW})} \\
-0.16^{\mathrm{NS}(\mathrm{c})(\mathrm{EW})} \\
-0.16^{\mathrm{NS}(\mathrm{c})(\mathrm{VW})}\end{array}$ & 3 years \\
\hline
\end{tabular}


Table 1 cont.

\begin{tabular}{llllll}
\hline Japanese Data & & & & \\
\hline Kang et al. (1999) & $1980-1988$ & 1329 & Control firm & $\begin{array}{l}-40.55^{* * *(\mathrm{EW})} \\
-44.55^{* * *(\mathrm{EW})}\end{array}$ & 5 years \\
\hline $\begin{array}{l}\text { Cheng et al. } \\
(2005)\end{array}$ & $1996-2002$ & 172 & Market model & $-0.039^{(\mathrm{EW})(\mathrm{d}) *}$ & 3 years
\end{tabular}

Notes: (a) Mean monthly abnormal return estimated using the alpha of the Fama and French model (1993). (b) Mean monthly abnormal return estimated using Fama and McBeth regressions. (c) Mean monthly abnormal return estimated using Carhart model (1997). (d) Mean daily abnormal return estimated using the alpha of the market model. EW: equally weighted abnormal returns. VW: value weighted abnormal returns. *** significant at $1 \%$ level; $* *$ significant at $5 \%$ level; ${ }^{*}$ significant at $10 \%$ level. NS: non-significant at conventional levels. \#: Statistical significance non reported by the authors.

These findings suggest two important conclusions. First, CB issuers' stock returns continue to decay during several post-issue months, suggesting that the negative market reaction observed at the time of the issue announcement was not proportional to the actual informational content of the news at that moment. ${ }^{1}$ In other words, investors' behaviour did not fully reflect the informational content of the CBs offering during the announcement period, but instead under-react. This "under-reaction" casts doubt on the market efficiency hypothesis at least under the semi-strong form. Second, CBs are issued following a run-up in the issuing firm stock price, suggesting that managers schedule CB issuance at a time when their stock prices are more likely to be over-valued.

Table 2: Previous Studies on Long-Run Operating Performance Following CB Issues

\begin{tabular}{|c|c|c|c|c|c|c|c|}
\hline \multirow{2}{*}{ Author(s) } & \multirow{2}{*}{ Country } & \multirow{2}{*}{$\begin{array}{l}\text { Performance } \\
\text { Measure }\end{array}$} & \multirow{2}{*}{ Benchmark } & \multirow{2}{*}{ Period } & \multirow{2}{*}{ Sample } & \multicolumn{2}{|c|}{ Operating Performance (\%) } \\
\hline & & & & & & Pre-Issue & Post-Issue \\
\hline $\begin{array}{l}\text { Hansen and } \\
\text { Crutchley (1990) }\end{array}$ & US & ROA & $\begin{array}{l}\text { Reference } \\
\text { portfolio }\end{array}$ & $1975-1982$ & 67 & $?$ & {$\left[-2.08^{* * *} ;-1.99^{* * *}\right]$} \\
\hline $\begin{array}{l}\text { McLaughlin et al. } \\
\text { (1998) }\end{array}$ & US & ROA & $\begin{array}{l}\text { Reference } \\
\text { portfolio }\end{array}$ & $1980-1993$ & 828 & $+0.4^{*}$ & $-0.2^{*}$ \\
\hline $\begin{array}{l}\text { Lewis et al. } \\
\text { (2001) }\end{array}$ & US & ROA; ROS & Control firm & $1979-1990$ & 566 & $?$ & {$[-1.61 ;-0.95]^{(\#)}$} \\
\hline $\begin{array}{l}\text { El Badraoui and } \\
\text { Lilti (2012) }\end{array}$ & Canada & ROA; ROS & Control firm & $1990-2006$ & 95 & {$\left[+0.13^{\mathrm{NS}} ;+1.07^{\mathrm{NS}}\right]$} & {$\left[-5.95^{* * *} ;-3.48^{* *}\right]$} \\
\hline
\end{tabular}

Notes: Unless stated otherwise, the pre-issue operating performance is measured by the median change in the abnormal operating performance over the period $(-2 ;-1)$, with year 0 being the offering fiscal year. The post-issue performance is measured by the median change in the abnormal operating performance over the three years following CBs offering. Intervals of performance are provided when several return metrics are used by the authors. \# Z-statistics testing, the equality of distributions between the change in the ratios between Years 0 and +4 using the Wilcoxon matched-pair signed-rank test. ? Performance values non reported by the authors. *** significant at $1 \%$ level; ** significant at $5 \%$ level; * significant at $10 \%$ level. NS: non-significant at conventional levels.

Several studies (Cf. Table 2) have further investigated the long-run operating performance of CB issuers following (respectively, before) the offering to determine whether the low (respectively, high) stock price performance of these firms is linked to changes in the profitability levels. McLaughlin et al. (1998) and Lewis et al. (2001), amongst other authors, show that issuing firms exhibit an operating profitability significantly lower than that of non-issuing firms over the three-year post-issue period. In addition, and consistent with the "window of opportunity" hypothesis (Loughran \& Ritter, 1997), these authors found out that CB issuers experience a significant increase in their abnormal operating performance before the offering. These findings suggest that firms schedule their $\mathrm{CB}$ offerings during periods of relatively high operating performance, performance levels which are not sustained post-offering.

Several studies point to the importance of controlling for security design in the analysis of the market reaction to the CBs announcements. Indeed, as pointed out by Lewis et al. (2003), CBs can be designed to alleviate various combinations of debt- and equity-related capital market imperfections. Therefore, an examination of average market reaction for the whole issuer universe is likely to be questionable and uninformative. In order to explain the cross-sectional variation in investors' reactions, Lewis et al. suggest to sort the sample of CB offerings into three groups depending on the level of equity-likeness of the CB as measured by its probability of conversion: equity-like CB (i.e., CB with a high probability of being converted into equity), mixed-like CB (i.e., CB for which the weight of equity and debt components are roughly the same) and debt-like CB (i.e., CB with a low probability of being converted into equity). According to the pecking order theory (Myers \& Majluf, 1984), the higher the equity component embedded in a financing instrument, the higher the probability that the firm is over-valued and,

${ }^{1}$ There is substantial evidence that the market reacts negatively to CB issue announcements. See Cheng et al. (2005) for a review. 
consequently, the more negative the information about the firm value. Along the same vein, some empirical studies have shown that the long-run performance of security issuers depends on the equity component embedded in the security offered. Lee and Loughran (1998) report that the magnitudes of the pre- and post-issue performances of CB issuers are closer but lower than those of firms conducting seasoned equity offerings. Indeed, according to these authors the post-issue wealth relative ratio for CB issuers is 0.83 compared to 0.79 for stock issuers. Spiess and Afleck-Graves (1999) report a significant mean Buy-and-Hold Abnormal Return (BHAR) of $-36 \%(t$-student $=$ 4.10) for the five-year period following CB issues. Although it is highly significant, this under-performance is lower than $-42.4 \%$ five-year performance decline that Spiess and Affleck-Graves (1995) report for equity issuing firms. In contrast, Spiess and Afleck-Graves (1999) find that straight debt issuers exhibit a non-significant mean BHAR of $14.30(\mathrm{t}=-1.16)$ in the five-year post-offering period. Likewise, Dichev and Piotroski (1999), Jewell and Livingston (1997), Cheng (1995), and Jung et al. (1995) find no reliable long-term abnormal returns following straight debt offerings. Also, while CB issuing firms over-perform their matched counterparts by $12.75 \%$ (significant at $1 \%$ level) over the six-months period prior to the offering announcement, Spiess and Affleck-Graves find no evidence of any statistically significant abnormal performance for straight debt issuers over the same period.

The above mentioned empirical evidence from the literature is also consistent with the market timing theory (see, e.g., Stein, 1996). This theory on security issuance states that managers use their private information opportunistically and issue equity when it is over-valued to take advantage of temporarily favorable market conditions. Therefore, stock prices of equity issuers should be more over-valued prior to the offering than stock prices of CB issuers, which in turn should be more over-valued than stock prices of straight debt issuers. As the market corrects the pre-offering misvaluation after the security issuance, the long-run post-issue performance is expected to be negatively related to the issuing firm's misvaluation. More specifically, the post-issuance long-run returns should be much smaller for equity issuers compared to CB issuers, while straight debt issuers should experience the lowest post-offering performance decline among the three types of security issuers.

CBs' design can be adjusted to be more equity-like or debt-like. In other words, debt-like offerings are issued as alternatives to straight debt, equity-like offerings are issued as alternatives to equity, and mixed-like offerings hold an intermediate position between equity and straight debt offerings. Therefore, and along the lines of the pecking order and the market timing theories of capital structure, we expect:

H1: Equity-like $\mathrm{CB}$ offerings to occur subsequent to strong performance run-up and to be followed by a large decline in the issuing firm performance.

H2: Debt-like issuers to experience no significant increase (respectively, decrease) in their performance before (respectively, after) CB offerings.

H3: The magnitude of pre- and post-issue performances of Mixed-like CB issuers to lie between those of equity- and debt-like issuers.

\section{SAMPLE DESCRIPTION AND RESEARCH DESIGN}

In this section we shall describe our data sample, the method we use to classify CBs, and the procedure used for matching issuing and non-issuing firms.

\subsection{Data}

Our initial sample consists of all CB issues listed in the monthly information bulletins of the Autorite des Marchés Financiers $(A M F)^{2}$ conducted by French public companies between January, 1990 and December, 2007 on the Paris stock exchange. It amounts to 231 offerings. Note however that our final sample consists of 133 issues conducted by 121 companies as a result of using the following filters:

1. The issuing firm must be an operating company (31 offerings excluded);

2. No subscription warrant, option or right should be attached to the CB being offered (18 offerings excluded).

\footnotetext{
${ }^{2}$ This French institution is the equivalent of the American SEC.
} 
3. Issuing firms' daily stock prices must be available on Datastream database for the two years surrounding the offering date. Similarly, and for matching purposes, issuers' accounting data must be available on Worldscope database for the fiscal year preceding the offering (17 offerings excluded).

4. Finally, some firms are multiple issuers of CBs. Because we examine the multi-year pre and post-issue performances, a CB offering is kept in the sample insofar as it is neither preceded by a CB offer during the last three years, nor followed by another $\mathrm{CB}$ offer in the three subsequent years. Such restriction aims to accommodate dependence for statistical tests which would be induced by overlapping abnormal returns (32 offerings excluded).

\subsection{CBs Classification Method}

The classification of CBs in our study is based on the total conversion probability derived from André-Le Pogamp and Moraux (2004)'s valuation method of callable CBs. This measure takes into account the probability of early conversion induced by the call feature, which may be expressed as follows:

$\mathrm{P}_{\text {conv }}=\mathrm{P}\left(\mathrm{S}_{\mathrm{T}}>\mathrm{K}\right)+\mathrm{P}\left(\mathrm{S}_{\mathrm{T}} \leq \mathrm{K}: \mathrm{S}_{\tau}>\mathrm{CP}\right)$

More formally:

$\mathrm{P}_{\text {conv }}=\mathrm{N}\left(\mathrm{d}_{2}\right)+\left(\frac{\mathrm{CP}}{\mathrm{S}}\right)^{2\left(\frac{\mathrm{r}-1 / \mathrm{\sigma}^{2}}{\sigma^{2}}\right)} * \mathrm{~N}\left(\mathrm{~d}_{2}^{\prime}\right)$

where $S$ denotes the closing underlying stock price prior to the announcement date, $K$ denotes the conversion price; i.e., the redemption price of the convertible debt, $C P$ denotes the contractual call price, $r$ denotes the riskfree interest rate calculated as the continuously compounded annual yield on 5-year French Government Bonds on the day preceding the announcement day, $\sigma$ denotes the standard deviation of the continuously compounded equity return estimated over the period 240 to 40 trading days prior to the announcement date, $T$ denotes the number of years until maturity, $N($.$) denotes the cumulative probability under a standard normal distribution function,$

$\mathrm{d}_{2}=\frac{\operatorname{Ln}(\mathrm{S} / \mathrm{K})+\left(\mathrm{r}-1 / 2 \sigma^{2}\right) \Gamma}{\sigma \sqrt{\mathrm{T}}}$, and $\mathrm{d}_{2}^{\prime}=\left(-\frac{\operatorname{Ln}\left(\frac{\mathrm{CP}}{\mathrm{KS}}\right)+\left(\mathrm{r}-1 / 2 \sigma^{2}\right) \Gamma}{\sigma \sqrt{\mathrm{T}}}\right)$. In sum, the conversion probability of CBs is equal to $\mathrm{N}\left(\mathrm{d}_{2}\right)$, computed using the standard Black-Scholes model, to which an adjustment factor related to early conversion is added; namely, $\left(\frac{\mathrm{CP}}{\mathrm{S}}\right)^{2\left(\frac{\mathrm{r}-1 / \sigma^{2}}{\sigma^{2}}\right)} * \mathrm{~N}\left(\mathrm{~d}_{2}^{\prime}\right)$.

Table 3: Distribution of French CB Offerings by Design and By Calendar Year in the Final Sample (1990-2007)

\begin{tabular}{|c|c|c|c|c|}
\hline Year & Full Sample & Debt-Like & Mixed & Equity-Like \\
\hline 1990 & 8 & 0 & 1 & 7 \\
\hline 1991 & 5 & 0 & 0 & 5 \\
\hline 1992 & 4 & 0 & 0 & 4 \\
\hline 1993 & 13 & 0 & 3 & 10 \\
\hline 1994 & 10 & 1 & 1 & 8 \\
\hline 1995 & 5 & 0 & 1 & 4 \\
\hline 1996 & 5 & 0 & 0 & 5 \\
\hline 1997 & 9 & 5 & 1 & 3 \\
\hline 1998 & 8 & 0 & 2 & 6 \\
\hline 1999 & 13 & 1 & 4 & 8 \\
\hline 2000 & 7 & 1 & 4 & 2 \\
\hline 2001 & 9 & 0 & 5 & 4 \\
\hline 2002 & 7 & 2 & 5 & 0 \\
\hline 2003 & 5 & 1 & 4 & 0 \\
\hline
\end{tabular}


Table 3 cont.

\begin{tabular}{lcccc}
\hline 2004 & 6 & 4 & 2 & 0 \\
2005 & 7 & 3 & 3 & 1 \\
2006 & 4 & 0 & 4 & 0 \\
2007 & 8 & 1 & 6 & 1 \\
\hline Total & 133 & 19 & 46 & 68 \\
\hline
\end{tabular}

Notes: CBs issues are by French industrial firms during 1990 to 2007. They are classified into three categories based on their total conversion probability computed on the announcement date using the formula displayed in Equation (2). A CB is categorized as "debt-like" if the total conversion probability is less than $40 \%$, as "mixed" if the total conversion probability is between $40 \%$ and $60 \%$, and as "equity-like" if the total conversion probability is greater than $60 \%$.

The distribution of CBs in our final sample by calendar year and security design is provided in Table 3 . The number of CB issues varies considerably over time. The largest number of offerings, 13, is in 1993 and 1999, while the lowest number is in 1992 and 2006. With regard to their design, a little more than half of these offerings fall into the equity-like category, followed by about one third of mixed offerings, while only one sixth of the CBs in our sample are designed to offer a low conversion probability to their holders.

The descriptive evidence in Table 4 suggests that issuing firms and offerings characteristics depend on the security design of the CB. Indeed, debt-like issuers tend to be large firms with few growth opportunities, low profitability, and low level of capital expenditures. Whereas equity-like issuers are somewhat smaller firms compared to debt-like issuers, but with significantly higher growth opportunities and profitability. Finally, equitylike issuers invest capital at very high rates compared to issuers of other types of convertible debt.

Table 4: Descriptive Statistics for CB Issuers in Our Final Sample

\begin{tabular}{|c|c|c|c|c|}
\hline Variables & All Issues & Debt-Like & Mixed & Equity-Like \\
\hline \multicolumn{5}{|l|}{ Panel A: Issuers Characteristics } \\
\hline${ }^{(1)} T A$ & 4558.3 & 7634.9 & 3982.6 & 4088.1 \\
\hline${ }^{(2)} M V$ & 2442.1 & 4521.2 & 2241.2 & 1997.1 \\
\hline${ }^{(3)} M / B$ & 3.5 & 0.9 & 3.9 & 4.0 \\
\hline${ }^{(4)} P / E$ & 39.7 & 16.2 & 28.8 & 53.7 \\
\hline${ }^{(5)}$ Growth (\%) & 36.0 & 19.4 & 29.0 & 44.9 \\
\hline${ }^{(6)}$ Slacks $(\%)$ & 12.8 & 10.5 & 13.8 & 12.8 \\
\hline${ }^{(7)}$ Intangibles (\%) & 16.4 & 15.1 & 21.6 & 13.3 \\
\hline${ }^{(8)} \mathrm{ROA}(\%)$ & 4.1 & -2.9 & 3.5 & 6.4 \\
\hline${ }^{(9)} \mathrm{CF} / \mathrm{S}(\%)$ & 6.9 & -0.9 & 5.8 & 9.5 \\
\hline${ }^{(10)}$ Payout $(\%)$ & 14.6 & 7.7 & 16.1 & 15.3 \\
\hline${ }^{(11)}$ Capex. $(\%)$ & 12.2 & 6.2 & 12.3 & 13.7 \\
\hline${ }^{(12)}$ Leverage $(\%)$ & 26.2 & 26.4 & 27.2 & 25.5 \\
\hline${ }^{(13)}$ BETA & 0.7 & 0.6 & 0.7 & 0.7 \\
\hline${ }^{(14)} \mathrm{SD}(\%)$ & 0.4 & 0.5 & 0.4 & 0.4 \\
\hline \multicolumn{5}{|l|}{ Panel B: Offerings Characteristics } \\
\hline${ }^{(15)}$ Conv. Premium $(\%)$ & 31.9 & 38.1 & 36.3 & 27.3 \\
\hline${ }^{(16)}$ Issue size & 241.3 & 475.7 & 225.4 & 186.6 \\
\hline${ }^{(17)}$ Relative Size (\%) & 27.2 & 27.1 & 27.9 & 26.7 \\
\hline${ }^{(18)} Y T M(\%)$ & 5.3 & 3.7 & 4.7 & 6.1 \\
\hline${ }^{(19)}$ Maturity & 6.4 & 5.4 & 6.0 & 6.9 \\
\hline${ }^{(20)}$ Call protection period (years) & 2.5 & 0.7 & 2.9 & 2.8 \\
\hline
\end{tabular}

Notes: All variables are retrieved and measured at the end of the fiscal year prior to the offering, unless otherwise specified. (1) Book value of total assets. (2) Market capitalization. (3) Market capitalization divided by the book value of equity. (4) P/E: Market capitalization divided by the net profit. (5) Change in total assets calculated as the difference between the book value of assets at fiscal year-end immediately after the issue announcement date minus the book value of assets for the fiscal year-end prior to the issue announcement date, divided by the book value of assets at the fiscal year-end prior to the issue announcement. (6) Cash and short term investments scaled by the book value of total assets. (7) Total intangible assets divided by the book value of total assets. Equity systematic risk estimated by beta of the standard two-parameter market model over the 250-trading-day period preceding the offering announcement date. (8) Issuer stock returns cumulated over the 75-trading-day period preceding the offering announcement date. (9) Offering proceeds scaled by total assets. (10) Dividend payout ratio expressed as percentage of earnings. (11) Capital Expenditures (additions to fixed assets) as percentage of total assets. (12) Total debts divided by the book value of total assets. (13) Equity systematic risk estimated by beta of the standard two-parameter market model over the 250-trading-day period preceding the offering announcement date. (14) Annualized historical volatility estimated over the 250-trading-day period preceding the offering announcement date. (15) The percentage amount by which the price of the CB exceeds the underlying stock price at the offering announcement. (16) Gross proceeds of the issue. (17) Gross proceeds of the issue standardized by the market capitalization. (18) CB yield to maturity. (19) Number of years until the expiration date of the CB. (20) Number of years of call protection. 


\subsection{Matching Procedure}

To check whether a firm is performing well or poorly following a CB offering, we need to specify a benchmark against which the issuing firm can be compared. In this study, we choose to measure the long-run stock price performance of the issuing firms using the control firm. Indeed, according to Barber and Lyon (1997), the use of the control firm approach to calculate abnormal returns yields test statistics which are well specified.

To select the appropriate control firm we follow the matching procedure used by Jegadeesh (2000). To be more specific, the matched firm is the firm which has the closest size, market-to-book ratio, leverage, and Return on Assets (ROA). All these characteristics are aggregated in the following distance metric:

$D_{j}=\frac{\sum_{i=1}^{4}\left|\mu_{C B(i)} \mu_{j(\mathrm{i})}\right|}{\sigma_{i}}$

where $\mu_{C B(i)}$ (respectively, $\mu_{j(i)}$ ) denotes characteristic $i$ of the $\mathrm{CB}$ issuer (respectively, control firm $j$ ) and $\sigma_{i}$ denotes the cross-sectional standard deviation of characteristic $i$. The choice of the first matching characteristic; namely, firm size, is motivated by the fact that common stock returns are negatively related to the firm size (Banz, 1981). In this paper, firm size is proxied by the log of firm's total assets. The choice of the second matching characteristic; namely, market-to-book ratio, is motivated by the fact that growth opportunities as usually proxied by the market-to-book ratio, on one hand, and convertible debt issuers tend to have high market-to-book ratios (Stein, 1992), on the other hand. Also, as documented by Fama and French (1995) and Lakonishok et al. (1994), amongst other authors, stocks with high market-to-book ratio (i.e., growth stocks) exhibit average returns which are significantly higher than those with low market-to-book ratio (i.e., value stocks). In this paper, we measure a firm's book-to-market ratio using the book value of common equity reported on the firm's balance sheet in year t-1 divided by the market value of common equity in December of year t-1, as suggested by Barber and Lyon (1997). The choice of the third matching characteristic; namely, leverage, is motivated by the fact that leveraged firms with high information asymmetries and profitable future investment opportunities would issue convertible debt (Stein, 1992). Also, the risk shifting hypothesis suggests that the presence of risky straight debt exacerbates the bondholders/shareholders conflicts about new investment projects, which leads companies to offer convertible debt to minimize these conflicts. In this paper, we compute leverage as the ratio of long-term debt on total assets. Finally, the choice of the last matching characteristic; namely, ROA, is motivated by the fact that previous empirical evidence has shown that convertible debt issuers experience a significant pre-issue performance, suggesting that firms tend to issue CBs over periods of high earnings and stock price performance (e.g., McLaughlin et al., 1998; Lewis et al., 2001). In this paper, ROA is computed as EBITDA (Earnings Before Interest, Taxes, Depreciation, and Amortization) on total assets. Recall that the control firm is the firm with the smallest distance metric from the issuing firm. Note that when the control firm is delisted from Datastream database while the issuer is still trading, a replacement matching firm is spliced in on a point-forward basis. Note also that when an issuing firm gets delisted, we remove at the same time its control firm. Our control sample consists of all French companies meeting the following criteria. The control firm should be listed on Datastream database and should not have carried out any offer of CBs during the six years surrounding the date of the CB offering conducted by the corresponding issuing firm. To be consistent with the CB issuer sample selection criteria, we exclude financial firms from the control sample. Finally, owing to the existence of extreme observations in our sample, two non-parametric tests are used to test the statistical significance of the differences in performance between the issuing firms and their matched counterparts; namely, the bootstrapped t-test and the Wilcoxon test.

\section{RESULTS}

We examine the stock price performance of CBs issuing firms over four event windows around security offerings. The first one starts one year before the offering and ends one month before the announcement date. The second, third, and fourth event periods start one month after the offer date and end one year, two years, and three years after the offer date, respectively. Table 5 below presents the average and the median of cumulative abnormal returns (CARs) along with the wealth relative. 
Table 5: The Long-Run Stock Price Performance of French CB Issuers (1990-2007)

\begin{tabular}{|c|c|c|c|c|}
\hline Event window & $-12 ;-1$ & $+1 ;+12$ & $+1 ;+24$ & $+1 ;+36$ \\
\hline Mean\% & $18.18 * * *$ & -3.95 & $-11.99 *$ & $-18.16^{* *}$ \\
\hline Bootstrap. $t$-test & 3.64 & -0.73 & -1.83 & -1.98 \\
\hline Median\% & $13.67 * * *$ & 0.01 & -11.31 & $-13.26^{*}$ \\
\hline$z$-wilcoxon & 3.27 & -0.46 & -1.32 & -1.71 \\
\hline Wealth relative & 1.16 & 0.96 & 0.89 & 0.84 \\
\hline $\mathrm{N}$ & 133 & 133 & 133 & 130 \\
\hline
\end{tabular}

Notes: This table presents the CARs of French CB issuing firms for the overall sample. CARs are computed over four periods: 12 months prior to the offering, 12 months, 24 months, and 36 months following the offering. Each issuing firm is matched with a non-issuing firm based on the distance metric in Equation 3. The bootstrap t-test is based on the bootstrap standard error estimated as follows: $S E_{\text {boot }}=\sqrt{\frac{1}{999} \sum_{k=1}^{1000}\left(\overline{C A R_{k}^{*}}-\frac{1}{1000} \Sigma \overline{C A R_{k}^{*}}\right)^{2}}$, where $\overline{C A R_{k}^{*}}$ denotes the mean CAR generated from the bootstrapped resample $\mathrm{k}=1, \ldots ., 1000$. $* * *$ Significant at $1 \%$ level, **Significant at $5 \%$ level, * Significant at $10 \%$ level.

Recall that wealth relatives are used to measure abnormal returns and are defined as the average gross stock return of the issuers divided by the average gross stock return for the matching firms. Thus, wealth relatives greater than one imply that issuers have higher returns than their matching firms, whereas wealth relatives less than one imply under-performance by the issuers compared to their matching firms.

The results reported in Table 5 suggest that French CB issuers experience a substantial increase in their stock price profitability over the year preceding the offering, with a mean of $18.18 \%$ ( $p$-value $<0.001$ ) and a wealth relative of 1.16. This pattern is in line with previous empirical studies providing strong evidence of large stock price run-up before convertible debt issues (e.g., Lee \& Loughran, 1998; McLaughlin et al., 1998; Lewis et al., 2001). This stock price run-up is consistent with the interpretation that CB offerings, like equity offerings, are signals that the issuing firm is over-valued. The results are reversed post-offering. In fact, over the 3-year post-issue window, the average CAR is $-18.16 \%$ - this under-performance is statistically significant at $5 \%$ level using the bootstrapped ttest. Although its magnitude is smaller and its statistical significance marginal, the median 3-year performance is also significantly negative. Our empirical evidence suggests that $\mathrm{CB}$ issuers' under-performance becomes more noticeable and statistically more significant as the length of the post-offering event window increases. The decreasing pattern in the wealth relative ratio lends support to this observation; it drops down from 0.96 over the year following the offer to 0.89 and 0.84 over two-year, and three-year post-issue window, respectively. This supports the hypothesis that the poor performance of $\mathrm{CB}$ offerings can be attributed to managers exploiting "windows of opportunity" through the issuance of over-valued securities.

Table 6: Long-Run Stock Returns Performance of French CB Issuers Sorted by Security Design

\begin{tabular}{lcccc}
\hline Event window & $-12 ;-1$ & $+1 ;+12$ & $+1 ;+24$ & $+1 ;+36$ \\
\hline Panel A: Debt-Like Offers & & & & \\
\hline Mean\% & 20.26 & 1.60 & -10.89 & 8.09 \\
Bootstrap. $t$-test & 1.20 & 0.15 & -0.73 & 0.35 \\
Median\% & 7.81 & 0.82 & -20.54 & -2.30 \\
$z$-wilcoxon & 0.80 & 0.81 & -0.44 & 0.16 \\
Wealth relative & 1.17 & 1.01 & 0.91 & 1.07 \\
\hline $\mathrm{N}$ & 19 & 19 & & 19 \\
Panel B: Mixed Offers & & & -10.57 & -22.61 \\
Mean\% & $14.98 *$ & -8.05 & -0.87 & -1.37 \\
Bootstrap. $t$-test & 2.11 & -0.89 & -11.36 & -12.57 \\
Median\% & $13.14 *$ & 0.06 & -0.74 & -1.18 \\
$z$-wilcoxon & 1.70 & -0.77 & 0.89 & 0.80 \\
Wealth relative & 1.14 & 0.92 & 46 & 44 \\
\hline $\mathrm{N}$ & 46 & 46 & & 46 \\
\hline
\end{tabular}


Table 6 cont.

\begin{tabular}{lcccc}
\hline Panel C: Equity-Like Offers & & & & \\
\hline Mean\% & $19.77 * * *$ & -2.73 & -13.25 & $-22.68 * *$ \\
Bootstrap. $t$-test & 3.07 & -0.35 & -1.47 & $-2,00$ \\
Median\% & $13.94 * * *$ & -0.50 & -9.29 & -17.87 \\
$z$-wilcoxon & 2.68 & -0.17 & -0.93 & -1.56 \\
Wealth relative & 1.18 & 0.97 & 0.88 & 0.80 \\
\hline N & 68 & 68 & 68 & 67 \\
\hline
\end{tabular}

Notes: This table presents the CARs of French CB issuing firms sorted by security design. CB issues are classified into three categories based on their total conversion probability computed on the announcement date using the formula displayed in Equation (2). A CB is classified as "debtlike" if the total conversion probability is less than $40 \%$ (Cf. Panel A), as "mixed" if the conversion probability is between $40 \%$ and $60 \%$ (Cf. Panel B), and as "equity-like" if the conversion probability is greater than $60 \%$ (Cf. Panel C). CARs are computed over four periods: 12 months prior to the offering, 12 months, 24 months, and 36 months following the offering. Each issuing firm is matched with a non-issuing firm based on the distance metric in Equation 3. The bootstrap t-test is based on the bootstrap standard error estimated as follows: $S E_{\text {boot }}=\sqrt{\frac{1}{999} \sum_{k=1}^{100}\left(\overline{C A R_{k}^{*}}-\frac{1}{1000} \sum \overline{C A R_{k}^{*}}\right)^{2}}$, with $\overline{C A R_{k}^{*}}$ the mean CAR generated from the bootstrapped resample $\mathrm{k}=1, \ldots ., 1000 . * * *$ Significant at $1 \%$ level, **Significant at $5 \%$ level, * Significant at $10 \%$ level.

We now partition CB offerings based on the design of the CB into debt-like, mixed, and equity-like CBs, and report the long-run pre- and post-issue performance in Table 6. We observe that CB issuers over-perform their matched counterparts in the three groups before the offering. However, this over-performance is statistically significant only for mixed and equity-like issuers with means of $14.98 \%$ ( $p$-value 0.07 ) and $19.77 \%$ (p-value < 0.001 ), respectively. After the issue, stock prices abnormally decline for mixed and equity-like issuers. This decline is more pronounced and statistically significant for firms that have experienced high appreciation in market value before the offering; namely, equity-like issuers. Their mean long-run performance has declined from $-2.73 \%$ (not significant at conventional levels) one year after the issue date to $-22.68 \%$ (significant at $5 \%$ level) three years later. Our results suggest that the poor post-issue stock price performance and the pre-offer stock price run-up reported for the whole sample in Table 5 are primarily driven by CBs with a strong equity component. This finding supports the timing hypothesis, which suggests that managers intentionally time their equity-linked securities offerings to take advantage of any temporary mispricing of the underlying stock.

Our findings also lend support to the pecking order theory of Myers and Majluf (1984), which implies that, under asymmetric information about the firm value, the issuance of equity securities conveys less favorable information about the firm's investment opportunities and assets in place than do debt securities offerings. The mean and median pot-offering CARs of the three sub-samples of CBs issues are in accordance with Myers and Majluf model. Indeed, CB offerings with low debt component (i.e., equity-like) are met by a statistically significant stock price decline, whereas offerings of mixed CBs is greeted with less negative abnormal returns. Finally, debt-like offerings are followed by statistically insignificant abnormal returns. Our results provide, therefore, consistent support for our three hypotheses according to which the larger is the equity component of the $\mathrm{CB}$, the higher is the long-run stock price performance decline (respectively, increase) subsequent (respectively, prior) to the $\mathrm{CB}$ issuance.

To complete the study of the long-run stock price performance of issuing firms, we now investigate the effect of the $\mathrm{CB}$ design on the operating performance of offering firms. The objective here is to determine whether the low subsequent stock returns for the CB issuers is linked to changes in profitability levels. To be more specific, we analyse the change in some accounting profitability ratios before and after the offering. Our measure of operating performance is the Earnings Before Interest and Taxes (EBIT). We favor the use of EBIT over the net income since it is a cleaner measure of operating performance, because it is not affected by tax status or the capital structure of the firm. However, to check the robustness of our results, the net income was also used. Because the level of economic benefits depends on the size of the firm, we scale the operating profit by the asset value (i.e., ROA), thus obtaining a performance measure that can be used to compare across firms and through time. However, as outlined by Barber and Lyon (1996), the main problem with scaling operating income by the book value of assets is that operating income may not be appropriately matched with the assets used to generate that income. Indeed, total assets reflects all assets of the firm, both operating and non-operating. In addition, total assets are recorded at historic cost, while operating income is reported in current currency. To address these issues, two alternative performance measures 
were constructed by scaling operating profit by total sales; namely, Operating Profit Margin (OPM) - computed as EBIT expressed as a percentage of total revenue, and Net Profit Margin (NPM) - computed as net income on total revenue. We examine the issuing firm operating performance over six years around the offering fiscal year (designated as year 0 ). Changes in operating performance are computed relative to year -1 over two event windows. The first one $(-1 ;-2)$ measures the issuing firm performance before the offering. The second one $(-1 ;+3)$ is designed to capture the operating performance subsequent to the CBs offering. We measure the abnormal operating performance of the issuing firm $i$ in fiscal year $\mathrm{t}\left(A P_{i t}\right)$ against the control firm ${ }^{3} I$ as follows:

$$
\mathrm{AP}_{\mathrm{it}}=\left(\mathrm{P}_{\mathrm{it}}-\mathrm{P}_{\mathrm{i},(\mathrm{t}-1)}\right)-\left(\mathrm{P}_{\mathrm{It}}-\mathrm{P}_{\mathrm{I},(\mathrm{t}-1)}\right)
$$

where $P_{i t}$ and $P_{i t}$ denote the operating return of the issuing firm $i$ and the control firm $I$ in the fiscal year $t$, respectively.

Panel A of Table 7 reports the changes in the operating performance for the whole sample of French CB issuers during the pre- and the post-offering period. Similar to previous empirical evidence in the American market, the median performance change is positive before the offering whatever is the accounting profitability metric used (i.e., ROA, OPM, or NPM). However, this increase is non-significant from a statistical standpoint. On the other hand, the pattern is different for the post-issue period. In fact, the median performance is negative and statistically significant at customary levels over the window $(-1 ;+3)$ indicating that the issuing firms experience a substantial decline in their operating performance subsequent to the offering as compared to their matching firms.

Table 7: Long-Run Operating Performance of French Issuing Firms Categorized by CB Design

\begin{tabular}{|c|c|c|c|c|c|c|}
\hline & \multicolumn{2}{|c|}{ ROA } & \multicolumn{2}{|c|}{ OPM } & \multicolumn{2}{|c|}{ NPM } \\
\hline & $-2 ;-1$ & $-1 ;+3$ & $-2 ;-1$ & $-1 ;+3$ & $-2 ;-1$ & $-1 ;+3$ \\
\hline \multicolumn{7}{|c|}{ Panel A: All Offerings } \\
\hline Median $\%$ & 0.32 & $-1.19 * *$ & 0.38 & $-2.22 * * *$ & 0.09 & $-1.4 * * *$ \\
\hline$z$-wilcoxon & 0.74 & -2.15 & 1.23 & -2.66 & 1.03 & -2.72 \\
\hline $\mathrm{N}$ & 121 & 108 & 121 & 108 & 121 & 108 \\
\hline \multicolumn{7}{|c|}{ Panel B: Debt-Like Offerings } \\
\hline Median $\%$ & 1.61 & 2.18 & 2.63 & 1.55 & $4.59 * *$ & 2.42 \\
\hline$z$-wilcoxon & 1.47 & 0.62 & 1.13 & 0.51 & 2.05 & 0.40 \\
\hline $\mathrm{N}$ & 15 & 15 & 15 & 15 & 15 & 15 \\
\hline \multicolumn{7}{|c|}{ Panel C: Mixed Offerings } \\
\hline Median $\%$ & -0.08 & 0.12 & -0.08 & $-3.15 * *$ & -0.32 & $-1.15 * *$ \\
\hline$z$-wilcoxon & -0.32 & -0.58 & -0.28 & -2.41 & -0.59 & -2.02 \\
\hline $\mathrm{N}$ & 43 & 39 & 43 & 39 & 43 & 39 \\
\hline \multicolumn{7}{|c|}{ Panel D: Equity-Like Offerings } \\
\hline Median $\%$ & 0.34 & $-3.13 * * *$ & 0.54 & $-2.27 *$ & 0.09 & $-2.21 * *$ \\
\hline$z$-wilcoxon & 0.49 & -2.73 & 1.23 & -1.71 & 0.71 & -2.38 \\
\hline $\mathrm{N}$ & 63 & 54 & 63 & 54 & 63 & 54 \\
\hline
\end{tabular}

Notes: CB issues are classified into three categories based on their total conversion probability computed on the announcement date using the formula displayed in Equation (2). A CB is classified as "debt-like" if the total conversion probability is less than 40\% (Cf. Panel B), as "mixed" if the conversion probability is between $40 \%$ and $60 \%$ (Cf. Panel $\mathrm{C}$ ), and as "equity-like" if the conversion probability is greater than $60 \%$ (Cf. Panel D). The operating performance is computed over two event periods: $(-2 ;-1)$ and $(-1 ;+3)$ with 0 being the offering fiscal year. ROA is defined as the EBITDA on total assets. OPM is defined as EBITDA on sales. NPM is defined as the net income on sales. Each issuing firm is matched with a non-issuing firm based on the distance metric in Equation 4 . ***Significant at $1 \%$ level, **Significant at $5 \%$ level, * Significant at $10 \%$ level.

Panels B, C, and D display our results when the whole sample is stratified into three sub-samples according to $\mathrm{CB}$ design. The median pre-offering operating performance is not statistically significant for any one of the three categories of issuers. This result is not consistent with our findings in Panels B and C of Table 6 which suggests that equity- like and mixed offerings are preceded by a significant stock price run-up. In the three years following the offering, equity-like issuers experience a significant decline in their operating performance. This result is robust with

\footnotetext{
${ }^{3}$ Note that the control firm is selected using the same procedure described in the previous section.
} 
respect to the various accounting profitability measures used. Similarly, mixed-like issuers exhibit a negative postoffering performance, but is statistically significant only when OPM and NPM are used as profitability measures. Debt-like issuers, however, do not show any significant post-issue abnormal return. These findings are globally consistent with our hypotheses expecting substantial post-issue operating performance decline for equity- and mixed-like issuing firms.

\section{CONCLUSION}

This paper investigates whether the long-run performance surrounding $\mathrm{CB}$ offerings depends on the security design. To this end, we first classify CBs in our sample into three categories based on their degree of equity-likeness as measured by the total conversion probability, namely: debt-like, mixed-like and equity-like CBs. Second, using the event study methodology, we compute the long run stock price and operating performance of each one of the three issuers' sub-samples around the CB issue.

Our results show, on one hand, that the larger the equity component of the $\mathrm{CB}$, the lower the post-offering long-run performance of the issuing firm. On the other hand, our empirical evidence concerning the pre-offering period indicates that only equity- and mixed-like CBs are issued prior to significant stock price run-up. These findings provide support to the pecking order theory and the market timing theory. Furthermore, they are consistent with previous empirical studies (e.g., Loughran \& Ritter, 1995; Spiess \& Affleck-Graves, 1999) suggesting that, in the long-run, equity and equity-linked securities' issuers under-perform (respectively, over-perform) their matched counterparts subsequent (respectively, prior) to the offering.

Finally, the findings of this study open other research avenues. For example, one could investigate whether the dynamics in systematic risk provide a rational explanation for the observed performance patterns across CB offerings per design class.

\section{AUTHOR INFORMATION}

Dr. Khalid El Badraoui is an Assistant Professor of Finance at Department of Finance \& Operations, ESC Rennes School of Business, Rennes, France. He has authored numerous articles, including publications in The International Journal of Business, Bankers Markets and Investors, Brussels Economic Review, and several other peer-reviewed journals. E-mail: khalid.elbadraoui@esc-rennes.fr (Corresponding author)

Dr. Jamal Ouenniche is a Lecturer in Management Science at the University of Edinburgh, Business School, Edinburgh, UK. His research focuses on the design and implementation of mathematical programming-based and artificial intelligence-based methods. His papers have been published in journals such as Operation Research, European Journal of Operational Research, and International Journal of Production Research. E-mail: Jamal.Ouenniche@ed.ac.uk

\section{REFERENCES}

1. Abhyankar, A., \& Ho, K. Y. (2006). Long-run abnormal performance following convertible preference share and convertible bond issues: New evidence from the UK. International Review of Economics and Finance, 15(1), 79-119.

2. André-Le Pogamp, F., \& Moraux, F. (2004). Valuing callable convertible bonds: A reduced approach. Applied Financial Economics, 14(10), 743-749.

3. Barber, B. M., \& Lyon, J. (1996). Detecting abnormal operating performance: The empirical power and specification of test statistics. Journal of Financial Economics, 42(3), 359-399.

4. Cheng, W., Visaltanachoti, N., \& Kesayan, P. (2005). A stock market reaction following convertible bond issuance: Evidence from Japan. International Journal of Business, 10(4), 323-339.

5. Dichev, I., \& Piotroski, J. (1999). The performance of long-run stock returns following issues of public and private debt. Journal of Business, Finance and Accounting, 26(9/10), 1103-1132.

6. Dutordoir, M., \& Van de Gucht, L. (2007). Are there windows of opportunity for convertible debt issuance? Evidence for Western Europe. Journal of Banking and Finance, 31(9), 2828-2846. 
7. Eckbo B. E., Masulis R. W., \& Norli O. (2000). Seasoned public offerings: resolution of the 'new issues puzzle.' Journal of Financial Economics, 56(2), 251-291.

8. El Badraoui K., \& Lilti, J. J. (2012). The long-run operating performance of Canadian convertible debt issuers: Trends and explanatory factors. International Journal of Business, 17(3), 299-324.

9. Fama, E. F., \& French, K. R. (1995). Size and book-to-market factors in earnings and returns. Journal of Finance, 50(1), 131-156.

10. Fama, E. F. (1998). Market efficiency, long-term returns, and behavioral finance. Journal of Financial Economics, 49(3), 283-306.

11. Hansen, R. S., \& Crutchley, C. (1990). Corporate earnings and financings: An empirical analysis. Journal of Business, 63(3), 347-371.

12. Jegadeesh, N. (2000). Long-term performance of seasoned equity offerings: Benchmarks errors and biases in expectations. Financial Management, 29(3), 5-30.

13. Kang, J. K., Kim, Y. C., \& Stulz, R. M. (1999). The underreaction hypothesis and the new issue puzzle: Evidence from Japan. The Review of Financial Studies, 12(3), 519-534.

14. Lakonishok, J., Shleifer, A., \& Vishny, R. W. (1994). Contrarian investment, extrapolation, and risk. Journal of Finance, 49(5), 1541-1578.

15. Lee, I., \& Loughran, T. (1998). Performance following convertible bond issuance. Journal of Corporate Finance, 4(1), 185-207.

16. Lee, C. F., Lee, K. W., \& Yeo, G. H. (2009). Investor protection and convertible debt design. Journal of Banking and Finance, 33(6), 985-995.

17. Lewis, C. M., Rogalski, R. J., \& Seward, J. K. (1998). Agency problems, information asymmetries, and convertible debt security design. Journal of Financial Intermediation, 7(1), 32-59.

18. Lewis, C. M., Rogalski, R. J., \& Seward, J. K. (1999). Is convertible debt a substitute for straight debt or for common equity. Financial Management, 28(3), 5-27.

19. Lewis, C. M., Rogalski, R. J., \& Seward, J. K. (2001). The long-run performance of firms that issue convertible debt: An empirical analysis of operating characteristics and analyst forecasts. Journal of Corporate Finance, 7(4), 447-474.

20. Lewis, C. M., Rogalski, R. J., \& Seward, J. K. (2003). Industry conditions, growth opportunities and market reactions to convertible debt financing decisions. Journal of Banking and Finance, 27(1), 153-181.

21. Loughran, T., \& Ritter, J. (1995). The new issues puzzle. Journal of Finance, 50(1), 23-51.

22. Loughran, T., \& Ritter, J. (1997). The operating performance of firms conducting seasoned equity offerings. Journal of Finance, 52(5), 1823-1850.

23. Lucas, M., \& McDonald, R. (1990). Equity issues and stock prices dynamics. Journal of Finance, 45(4), 1019-1044.

24. Mayers, D. (1998). Why firms issue convertible bonds: The matching of financial and real options. Journal of Financial Economics, 47(1), 83-102.

25. McLaughlin, R. M., Safieddine, A., \& Vasudevan, G. K. (1996). The operating performance of seasoned equity issuers: Free cash flow and post-issue performance. Financial Management, 25(4), 41-53.

26. McLaughlin, R. M., Safieddine, A., \& Vasudevan, G. K. (1998). The long-run performance of convertible debt issuers. Journal of Financial Research, 21(4), 373-388.

27. Myers, S. C., \& Majluf, N. (1984). Corporate financing and investment decisions when firms have information that investors do not have. Journal of Financial Economics, 13(2), 187-221.

28. Spiess, D. K., \& Affleck-Graves, J. (1995). Underperformance in long-run stock returns following seasoned equity offerings. Journal of Financial Economics, 38(3), 243-267.

29. Spiess, D. K., \& Affleck-Graves, J. (1999). The long-run performance of stock returns following debt offerings. Journal of Financial Economics, 54(1), 45-73.

30. Stein, J. C. (1992). Convertible bonds as a backdoor equity financing. Journal of Financial Economics, 31(1), 3-21.

31. Stein, J. C. (1996). Rational capital budgeting in an irrational world. Journal of Business, 69(4), 429-455. 